\title{
2012 年 4 月 3 日爆弾低気圧到来時における 首都圈通勤・通学者の帰宅行動に関する質問紙調査 \\ QUESTIONNAIRE SURVEY CONCERNING STRANDED COMMUTERS IN METROPOLITAN AREAS BY THE APPROACH OF BOMB CYCLONE ON APRIL 3, 2012
}

\author{
廣井悠*
}

\section{U HIROI}

\begin{abstract}
In this paper, we discuss a questionnaire survey concerning stranded commuters in the metropolitan area by approaching the bomb cyclone on April 3, 2012. Based on the results of the survey, when the bomb cyclone approached, nearly 90 percent of commuters recognized arrival of the bomb cyclone beforehand. And nearly 60 percent of commuters received instruction to return home at once from own company. But only 78 percent of people followed the instructions. Many people received the directions about return home rather than the time of the Great East Japan Earthquake. And, 59.9\% of respondents answered "There are no plan and training about stranded commuters in our company." It means that there are also many companies which has no plan about stranded commuters.
\end{abstract}

Keywords : bomb cyclone, stranded commuters, East Japan Great Earthquake, questionnaire survey 爆弹低気圧，帰宅困難者，東日本大震災，質問紙調查

\section{1. はじめに}

2012 年 4 月 3 日から 5 日にかけてわが国を襲った台風並みの巨 大な低気圧は広い範囲で瞬間風速 $30 \mathrm{~m}$ 以上を記録し注1), 九州から 北海道にかけて各地に被害や混乱をもたらした。 これによって全国 で 5 名が死亡, 350 人以上が重軽傷を負い, 他にも停電・建物被害・ 倒木・鉄道の運休などの各被害が報告されている 1 ), 2). このように 低気圧が急速に発達し, 強い風雨やそれに伴う被害を起こす現象は 近年しばしばみられており注 2), 一般に爆弾低気圧(bomb cyclone, bomb-low) と呼ばれている注3).

そもそもこの爆弾低気圧は 4 月 2 日に中国の黄海沿岸で発生した ものであり, 4 月 3 日の朝に日本海に到達, 当日午前から西日本を 暴風雨が襲い, 午後には東日本に拡大していくという経緯を辿った が, 特に首都圈では低気圧の直撃が帰宅ラッシュの時間を襲ったこ ともあり, 鉄道の運休や飛行機の欠航が相次ぐとともに多数の乗客 の足を止めることとなった。これに対し, 各企業は東日本大震災や 2011 年台風 15 号の教訓を生かして早期帰宅や職場待機を社員に促 し, 東京都も 3 日昼に広く一斉帰宅の抑制と鉄道各社への運休時の 利用者保護を求めるなどした結果, 混乱は東日本大震災時ほど大き なものではなかったとの報道がなされている ${ }^{3), 4) .}$

しかし一口に「帰宅困難」とはいえ，大規模地震に起因寸る帰宅 困難現象と爆弾低気圧や台風による帰宅困難現象では発生の経緯か
ら被災の状況，並びに通信状況などに関して与えられた環境は大き く異なるものである、それゆえ，あるべき対策方針もまた対策の意 義すらも，多少の差異が伴うものである．よってこのような事実・ 報道のみでは東日本大震災の経験がどのように，あるいはどの程度 生かされたかは一概には断定できないものと考えられる。他方で, 2013 年以降全国各地で策定がす寸みつつある安全確保計画のなか には風水害を対象とする計画もあり，大都市における風水害時の帰 宅困難状況を記録する意義も今後の対策に資するものと考えられる. そこで本研究では，2012 年 4 月 3 日に到来した爆弾低気圧に関 する個人や企業の対応について質問紙調査を行い, 当日の帰宅行動 のみならず，企業の指示や情報入手の状況に関する実態を把握し， 今後の帰宅困難者対策のあり方について検討を行った．本研究はお おむね大規模地震時の帰宅困難者対策を想定に入れて概要をまとめ るものであるが，今後はこのような爆弾低気圧の頻度や規模が増加 することも考えられ，このような状況下での対応行動を考えること は注意喚起の面も含め有意義な試みといえよう。それゆえ，ここで は特に企業の帰宅に関する指示や就業者の帰宅に関する判断基準, 帰宅困難を想定した計画や進捗について焦点を絞って記述する.

つまり, 本研究の主目的は以下の 2 点で整理され, これらの知見 を地震災害時の帰宅困難者対策，特に企業が行う「一斉帰宅の抑制」 に生か寸目的でまとめた「調査研究」としての性格を有する.

1. 就業者の帰宅行動に関する判断基準や指示の内容を把握する.

* 名古屋大学減災連携研究センター 准教授. 工博 Assoc. Prof., Disaster Mitigation Research Center, Nagoya University, Dr. Eng. 
2. 企業の帰宅困難者対策に関する対策状況などを整理する.

ところで本研究で行った調査は, 東日本大震災の発生から約 1 年 後に行ったものであり, 後述する東日本大震災直後に行った州宅困 難者問題に関寸る質問紙調查と, ほぼ同様の対象者抽出条件を経て サンプル抽出を行っている (20 歳以上かつ当日首都圈に外出してい た回答者を居住都県・性別・年代ごとに等数となるよう抽出).この ため本調查は帰宅困難者対策の夕ならず，東日本大震災から 1 年が 経過した時点で調查対象者がどのような防災対策を行ったかを知り， また比較する絶好の機会と考えられる. そのため上記の 2 点に加え, 3. 個人が東日本大震災から 1 年の間に行った防災対策に関寸る 実施状況を整理する

というもう一つの目的を追加することとした．

\section{2. 調査の概要}

調査の概要は表 1 の如く示される。調査地域は 2012 年 4 月 3 日 当日, 東日本大震災と同じく多くの通勤者が帰宅困難状態になりう る可能性があった東京都, 神奈川県, 埼玉県, 千葉県を対象地とし て選び, そこに居住する 20 歳以上かつ 4 月 3 日午前 10 時に首都圈 に外出していた回答者を調査対象とすることとした。調査方法は Web 調查を用い, ネットリサーチモニター 20,046 人のなかから対 象サンプル 2158 人を抽出し, 本調査を実施している(サンプル選定 にあたっては, 20 歳以上かつ 4 月 3 日午前 10 時に首都圈に外出し ていた回答者がそれぞれ居住都県・性別・年代ごとに等数となるよ う抽出している)。このもとで, 当日の帰宅状況や気象情報の入手状 況, 帰宅に関する指示やその評価, 情報ニーズ, 今後の対策を尋㸚 た，以降では，本調查で得られたデータを集計することにより，当 日の実態を把握するとともに今後の帰宅困難者対策に関する示唆を 得るため, 論考を重衫る. 調查対象者の個人属性や, 外出理由など は図 1～図 3 の如くなる。 なお調查対象者 2158 人中, 男性は 1091 人，女性は 1067 人とほぼ同数であった.

表 1 アンケート調査の概要

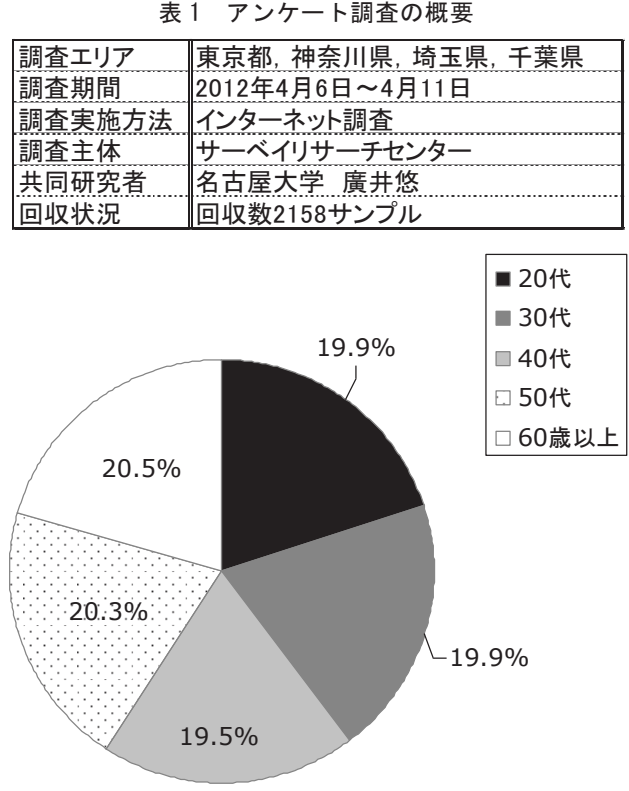

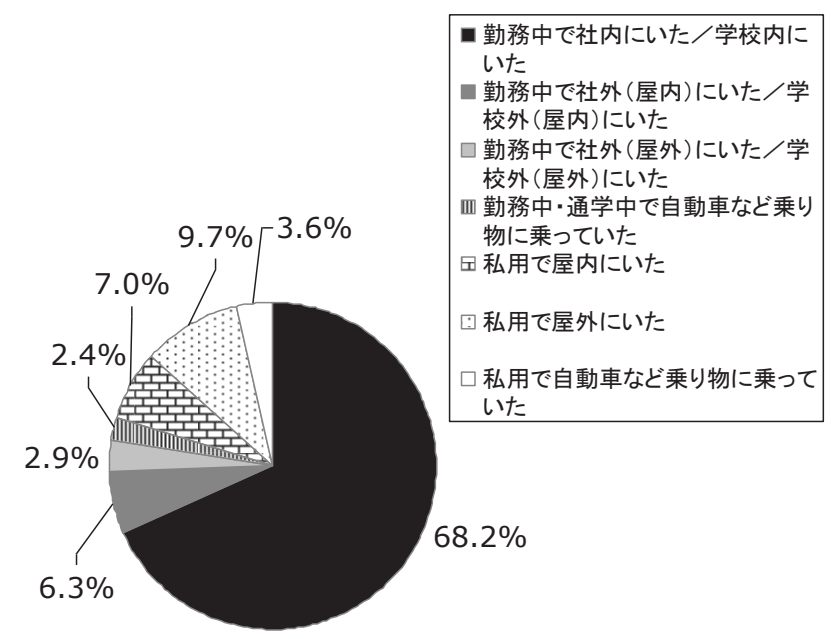

図 2 調査対象者の 4 月 3 日午前 10 時における 外出目的と居場所 $(\mathrm{N}=2158)$

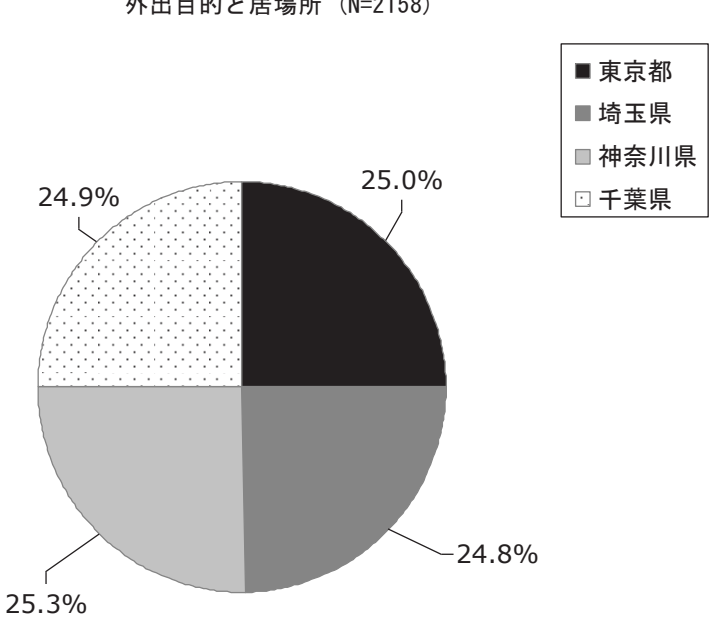

図 3 調査対象者の居住地 $(\mathrm{N}=2158)$

\section{3. 爆弾低気圧に関する認知や帰宅状況}

はじめに爆弾低気圧に関する認知や帰宅状況についてまとめる.4 月 2 日は気象庁が夕方に警戒を呼び掛け，事前対策や外出を控える 必要性が報道機関で報じられている。また東京都は 4 月 3 日昼の段 階で企業に（鉄道機関運行停止後の）「一斉帰宅の抑制」を求めて いる.このような状況下での認知や帰宅状況であることを理解され たい.さて認知状況であるが，4月 3 日に爆弾低気圧が発生したこ とを事前に知っていた人は $91.0 \%$ と極めて多かった。つまり，東日 本大震災時と異なり, 多くの回答者が爆弾低気圧の接近を事前にあ る程度予見していた中での帰宅困難状況だったわけである。それに 対して 4 月 3 日の帰宅時間の判断については，「公共交通機関が止 まる前に早期帰宅をしようとした」人が $55.1 \%$, 「帰宅を遅らせよ うとした」人が $7.1 \%$ ，「特に気にしなかった」と回答した人が $37.7 \%$ であった(図 4).これらにより，爆弾低気圧の到来を認知しつつも， 帰宅時間の変更を考えなかった人が比較的多かったことがここで判 明している。

図 1 調査対象者の年齢 $(\mathrm{N}=2158)$ 
—公共交通機関が止まる前に早期帰宅をしうとした 口帰宅を遅らせようとした

、特に気にしなかった

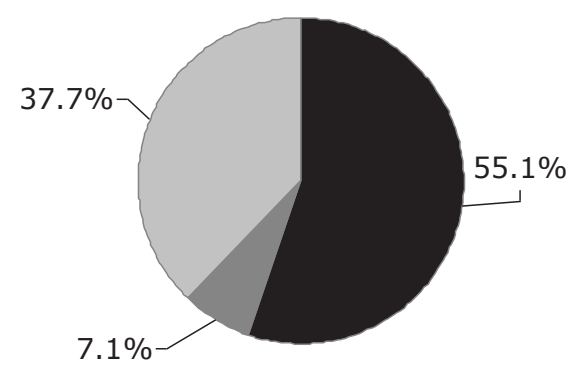

図44月 3 日の帰宅時間についてどのように判断したか $(N=2158)$

他方で, 爆弾低気圧に関する情報収集に用いた情報ツールは 88.8\%とテレビによるものがきわめて多く, ついで(SNS 以外の)イン ターネット $20.9 \%$, 新聞 $17.1 \%$ であた。家族からは $10.5 \%$, 友人・ 知人・会社の人などからは $11.0 \%$ であ, ツイッターやフェイスブ ック等の SNS によるものが 4.0\%である（図 5）。このことからも， ソーシャルメディアによる気象情報の入手は実際のところは比較的 少なく, やはりテレビやインターネット, 新聞による情報収集が圧 倒的であることが改めて確認できる. 当日の気象情報の入手につい て, 普段の確認行動と合わせて尋㸚たものが図 6 である.これによ ると「警報・注意報」については普段は $23.8 \%$ このこ情報を確認し ているが，4月 3 日については 46.8\%が確認している。「天気図」

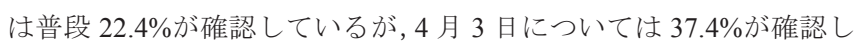
ている．また「雨雲の動き」は普段は $17.4 \%$ 花認しているが， 4 月 3 日については $31.5 \%$ 花認している. そして風予測については 普段は $11.4 \%$ 花認しているが, 4 月 3 日については $29.5 \%$ 花認し ている。その他は衛星画像( $4 / 3$ は 19.2\%が確認, 普段は $11.9 \%$ が確 認), 当日の天気, 当日の降水確率, 風予測, 確認していないなどで あるが, 総じて多くの人が従来よりも気象情報を受け取った中での 現象であった。この前提をもとに, 以降では帰宅状況について整理 する.さて，帰宅状況について記述したい，本調查によると，「当 時はいつもより時間がかかったが帰宅できた」という人が $29.2 \%$,

「州宅中にどこかに留まらざるを得なかった」という人が $2.5 \%$ あ った. 特に帰宅時間については, 普段の移動時間が 30 分未満の人は 78.8\%が「普段通り」であり，「普段より時間がかかった」という 人は $21.1 \%$ に過ぎなかった. 多少の混乱はあったものの, 影響は小 さいものとみることができる. 他方で普段の移動時間が 1 時間 30 分〜2 時間未満の人は $31.0 \%$ が「普段通り」であり，「普段より時 間がかかった」という人は $52.9 \%$ であ。これは東日本大震災時の 首都圈でもみられたことであるが, 帰宅時間については遠距離移動 者がより影響を受けていることが確認できる.

続いて,帰宅しようとしたきっかけを示す. 図 7 にもあるように, 「仕事や用事が済んだから」といら回答が一番多いが, 通勤・通学 者については「会社や学校, 団体から帰宅するよう指示が出たから」 が 29.0\%と次いで多く, 「所属する会社や学校, 団体からの指示で 帰宅してもよい時間となったから」も10.0\%いる.

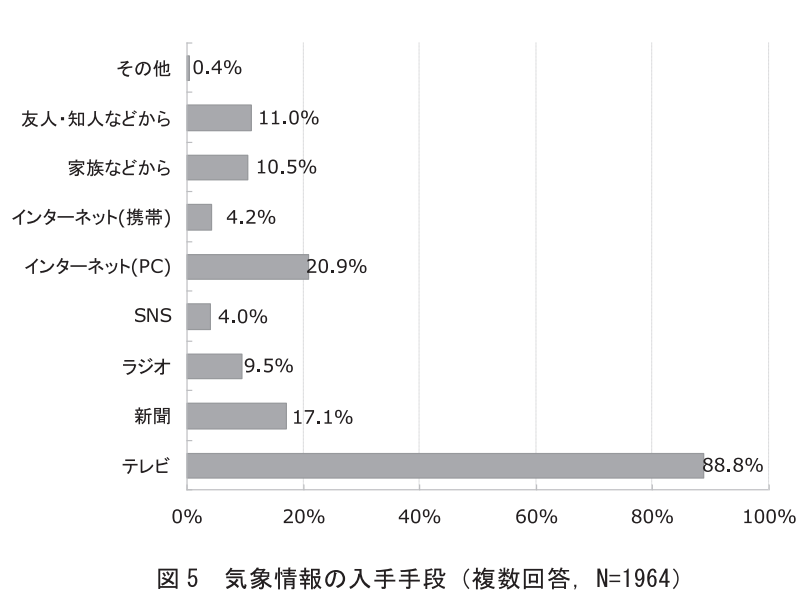

４月3日に確認した口普段確認している

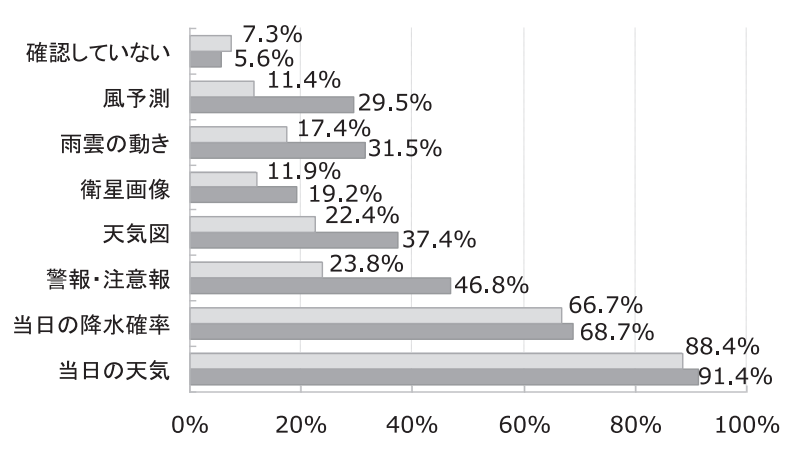

図 6 入手した気象情報の種類（複数回答, $\mathrm{N}=2158$ ）

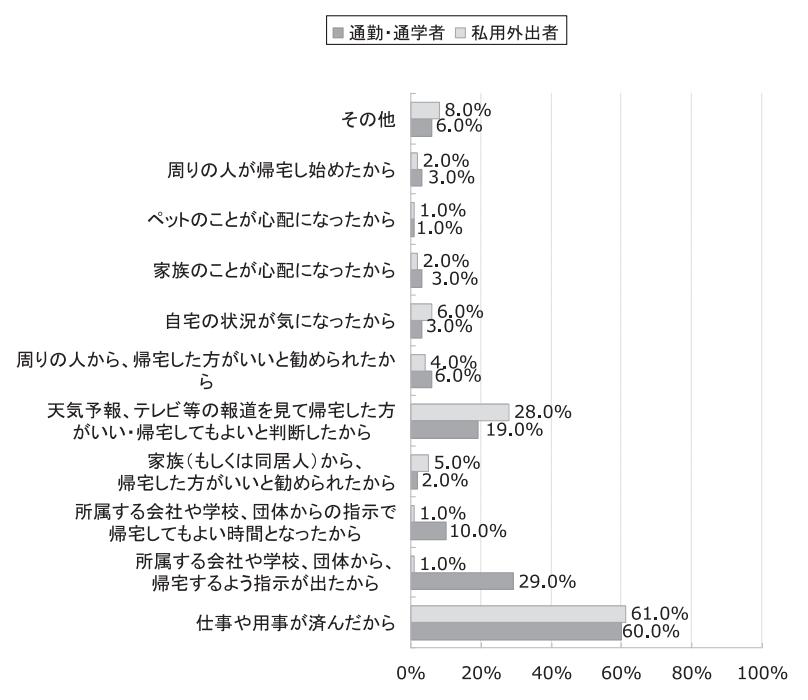

図 7 帰宅しようとしたきっかけ

（通勤 · 通学者 $\mathrm{N}=1722$, 私用外出者 $\mathrm{N}=436$ )

反対に買い物客などの私用外出者は, 「天気予報, テレビなどの 報道を見て帰宅した方がいい, 帰宅してもいいと判断したから」が $28.0 \%$ ，「自宅の状況が気になったから」が $6.0 \%$ ，「家族や同居人 から帰宅した方がいいと勧められたから」が 5.0\%となっている。こ 
のことから, 就業中や就学中は個人や家族の状況判断が州宅の決断 に繋がりにくく, そのような人たちには企業や学校からの適切な指 示が必要であるとの示唆が得られる. これは, 地震時など大規模災 害時も同様であろう。帰宅の抑制や早期帰宅などの判断を迅速に行 わせるには, 少なくとも通勤・通学者については, 企業などからの 指示や判断基準の明確化が必要になると考えられる.

\section{4. 帰宅の指示について}

それでは，爆弾低気圧到来時の企業の指示はどうであったのだろ うか.これ以降は通勤・通学者のみ $(\mathrm{N}=1722)$ の集計結果を示したい. はじめに「所属する会社や団体から 4 月 3 日の帰宅に関する指示が 出た」との回答はの心゙ $64.8 \%$ でった。このなかで「帰宅を促す指 示が出た」は $62.6 \%$, 「帰宅を控えて留まるような指示が出た」は $2.2 \%$ あるあ.また，「指示が出なかった」という回答は $34.7 \%$ で った(図 8) 注4). なおここでは, 帰宅を促す指示と帰宅を控えて留ま る指示の両方を受け取っている回答者もいる。これより， $2 / 3$ 程度 の回答者が帰宅に関する指示を受け取っていることが分かった。一 方で, その時間帯をみてみると, 当日指示を受け取った人が $65.9 \%$, 前日までに指示を受け取った人が $1.2 \%$, 前日までに出勤停止命令を 受け取った人が $0.2 \%$, 指示を受け取れなかった人が $32.8 \%$ となって いる。つまり, ほとんどが当日の指示になっている点が特徵的であ る. またこれは， 4 月 3 日当時に社内にいた人と社外にいた人で異 なることもわかった。社内にいた人で当日指示を受け取った人は $68.4 \%$ であり, 社外にいた人で当日指示を受け取った人は $50.8 \%$ であ る. 他方で社内にいた人で当日指示を受け取れなかった人は $30.6 \%$ であり，社外にいた人で当日指示を受け取れなかった人は $46.0 \%$ で ある.このように, 社外にいる人が相対的に指示を受け取りにくか ったことがわかった。
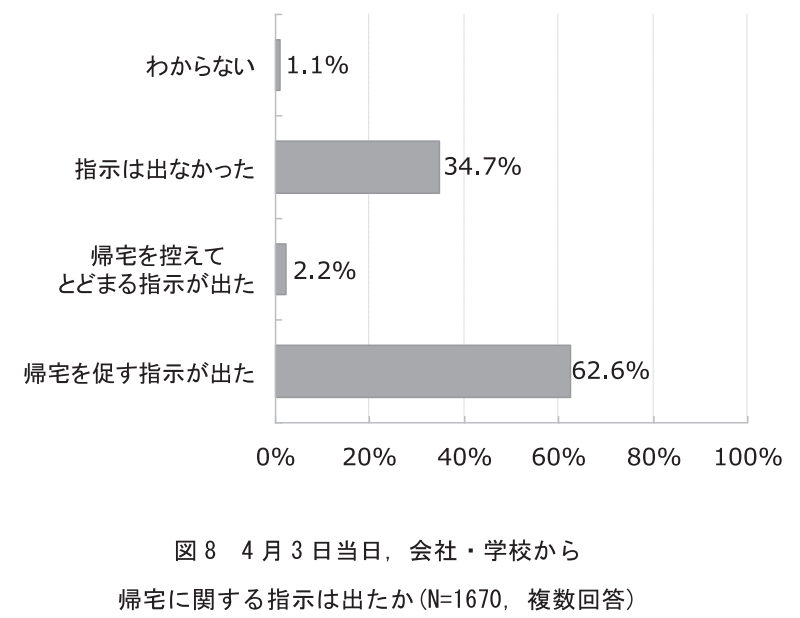

その主な理由として考えられるのは, 伝達手段である.「帰宅に 関する指示をどのような手段で受け取ったか」という設問に関する 回答を見ると,「口頭で受け取った」が $65.3 \%$ と一番多く, ついで 「PCメールで受け取った」が $27.3 \%$,「携帯電話で受け取った」が $5.4 \%$ であった注 5).PCメールで帰宅指示の $1 / 4$ がなされていた点は 興味深いが，このように帰宅指示に関する情報伝達手段はいまのと ころ口頭によるものが群を抜いて多く, それゆえ外出者に州宅指示 が伝わりにくい傾向にあることが課題として挙げられる.
次に, これらの指示に関する特徴について記述する.はじめに, 帰宅に関する指示があった時刻を示すと，前日に指示があったケー スが $1.7 \%$, 午前中(出勤前)が $2.9 \%$ と極めて少なく, 午前中(出勤後) が $24 \% ， 12$ 時台が $13.5 \% ， 13$ 時台が $25 \% ， 14$ 時台が $17 \%$ と大部分 が出勤後に集中している。これは東京都が 4 月 3 日昼の段階で企業 に(鉄道機関運行停止後の)「一斉帰宅の抑制」を要請したことも 影響したものと考えられる。一方で, 15 時以降に最初の指示があっ たといら回答も $18.4 \%$ あり, 指示が遅れた企業・学校があったこ とも明らかとなった。また，帰宅を促す時間の目途は 16 時以前(主 な終業時刻前)の帰宅を促した指示が $48.9 \%$ と多かったが，具体的な 時間指定がないものも $42.4 \%$ と多かった.

ここでは，質問紙上で指示が適切であったかどうかについても複 数回答で尋ねている(ただし指示を受け取れた回答者 $(\mathrm{N}=1127)$ のみ). その結果「指示の内容が適切でなかった」という回答は $9.9 \%$,「指 示の出た時間が適切ではなかった」という回答が $21.3 \%$, 「指示の 伝達手段が適切ではなかった」という回答が $3.9 \%$ あ゙った.一方「指 示の内容・出た時間・伝達手段ともに適切であった」という回答は $56.4 \%$ となっている.つまり, 約半数が帰宅に関する指示について 「適切」と評価しているものの, 指示の出た時間や指示の内容につ いて適切でなかったと感じている回答者もいたことになる.

それではこの「適切な指示」はどのように出されたものなのであ ろうか．これを知るため，帰宅に関する指示が出た時間とその評価 についての比較を行う。一般に気象災害時において帰宅に関する指 示は, 遅ければ遅いほど状況を正確に把握することができるため, 指示内容は適切になっていくものと考えられるが，早期帰宅などの 対応は難しくなる．他方で指示が早ければ早いほど様々な対応が可 能となるものの，指示内容は正確性に欠けると考えられる。図 9 は 両者の関係を示寸ものである。ここでは, 帰宅に関する指示の出た 時間として「前日 $(\mathrm{N}=19) 」, 「$ 午前中・出勤前 $(\mathrm{N}=32) 」, 「$ 午前中 • 出勤後( $N=269)\rfloor, \quad\lceil 12$ 時台 $(\mathrm{N}=150)\rfloor, \quad\lceil 13$ 時台 $(\mathrm{N}=253)\rfloor, \quad\lceil 14$ 時台 $(\mathrm{N}=192)\rfloor, 「 15$ 時台 $(\mathrm{N}=107)\rfloor,\lceil 16$ 時台 $(\mathrm{N}=71)\rfloor,\lceil 17$ 時

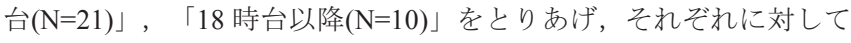
指示内容・出た時間・伝達手段ともに適切であった割合を示してい る。これを見ると, 帰宅に関する指示が速すぎても遅すぎてもその 指示は評価されておらず，午前中に指示が出た調查対象者が最もそ の指示を適切と評価する傾向が判明した。他方で, その指示に従っ たかどうかに関する回答について，指示に従わなかったと回答した 人が $21.3 \%$ いることが明らかになった(図 10).このなかで，このよ うに指示に従った人は何をきっかけとして帰宅したか見てみると， その 79\%が「仕事や用事が済んだから」という理由であり(指示に従 った人はこの理由がきっかけで州宅した人は $40.6 \%), 13 \%$ 「天気 予報などで帰宅した方がよいと思ったから」であった(指示に従った 人はこの理由がきっかけで州宅した人は $26.1 \%)$.つまり，指示に従 わなかった人はその多くが指示に従わず仕事や用事を行っており， 天気予報などによって帰宅するなどの判断もしていない，大震時に は，本調査の対象地域においては帰宅の抑制の指示が出る企業も多 いものと考えられるが，気象災害時において $1 / 5$ 程度の人数が早期 帰宅の指示を無視しているという点は，八ザードの質が異なるとは いえ課題と考えられる．少なくとも，これらの指示に対する実效性 をどのように確保していくかが今後求められよう. 


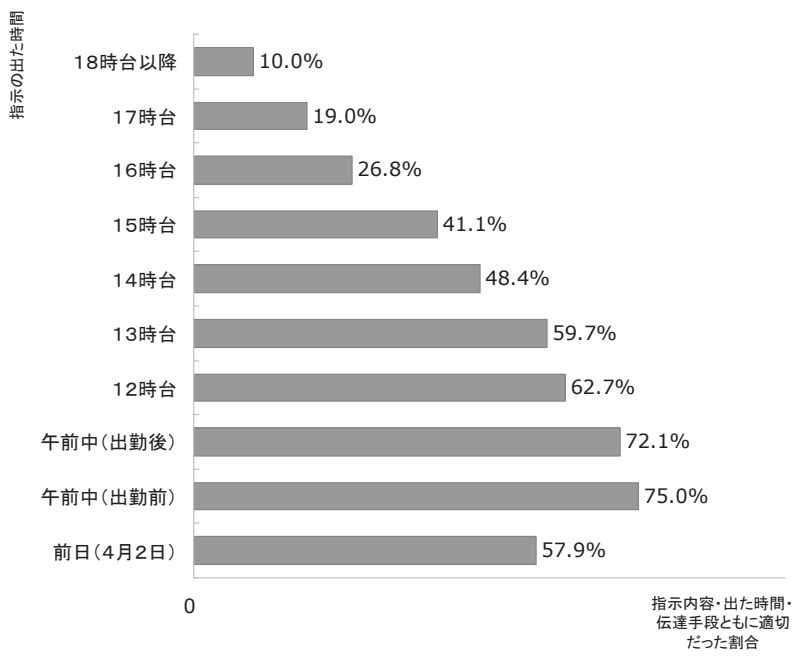

図 9 帰宅に関する指示の出た時間と指示内容の評価 $(N=1127)$

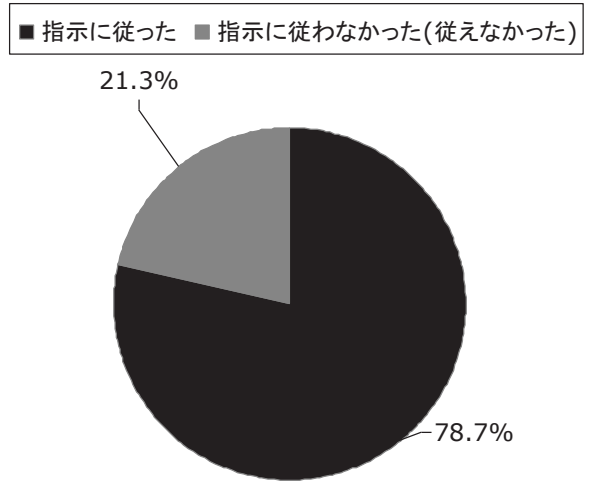

図 104 月 3 日当日, 会社・学校からの 帰宅に関する指示に従ったか（N=1127）

\section{5. 東日本大震災時との比較}

続いて東日本大震災時との比較について述べる ${ }^{5), 6), 7)}$.このとき, 著者らが東日本大震災の直後に行った帰宅困難者対策に関する質問 紙調查との比較で論じることとしたい。この調查概要は表 2 の如く なり, サンプル抽出やモニタの属性はほぼ同様のため（図 11）, 表 1 に示した回答者層と類似しているものと見ることができる.

図 12 は, 東日本大震災当日と爆弾低気圧襲来時に指示を受け取っ たかどうかの比較図である。通勤・通学者を対象としているため,

ここでは東日本大震災時の会社や学校・団体に所属していなかった 人を除いて算出を行った $(\mathrm{N}=1568)$. 結果として, 東日本大震災時に は帰宅に関する指示を受け取った人は $49.8 \%$ であり, 帰宅に関寸る 指示を受け取れなかった人は $8.6 \%$ であり, 帰宅に関する指示が出て いないと答えた人が $41.6 \%$ あることが分かった。つまり約半数の 回答者が帰宅に関する指示を受け取っているが，約 4 割の回答者が 所属する企業では帰宅に関する指示がでておらず， 1 割弱の回答者 は企業で指示が出ていながらもそれを受け取れていない. 2012 年 4 月 3 日に指示を受け取っている回答者は $67.3 \%$ でるため, 地震に よる帰宅困難と爆弾低気圧や台風による帰宅困難では状況や問題の 所在が違うとはいえ, 帰宅に関する指示を受けとったという回答も, 会社で帰宅に関する指示が出たという回答も今回は増加している.
表 2 東日本大震災直後に行ったアンケート調查の概要

\begin{tabular}{|c|c|}
\hline 調査エリア & 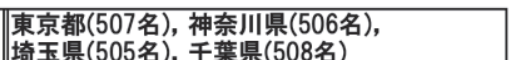 \\
\hline 調直 & 2011 年3月25日 2011 年3月28 \\
\hline 調查雵施方法 & インターネット調查 \\
\hline 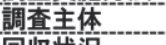 & 粉京天学，東洋大学，开 \\
\hline
\end{tabular}

$\square$ 爆弾低気圧 $\square$ 東日本大震災

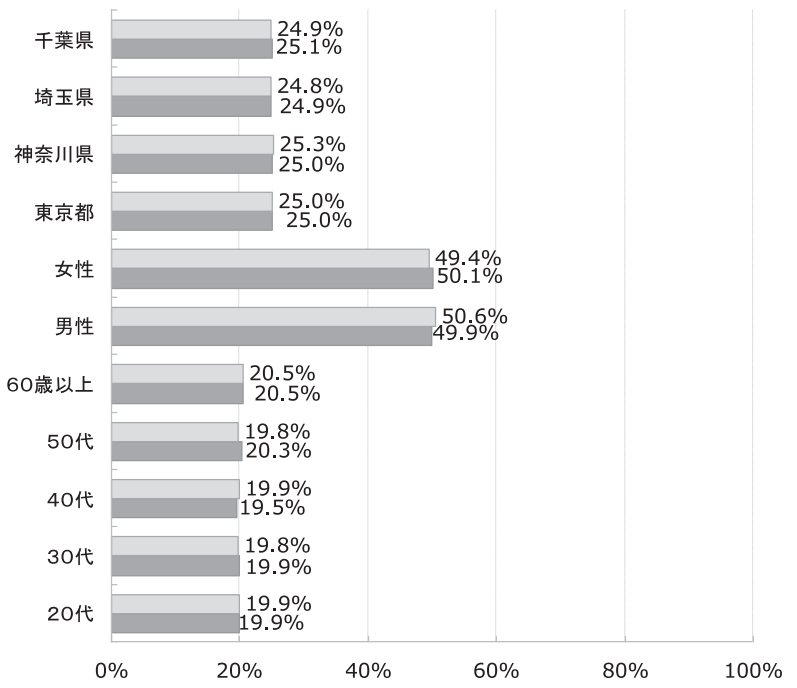

図 11 表 1 (爆弹低気圧)，表 2 (東日本大震災）に示した 2 種類の質問紙調 査における調査対象者の属性比較（居住地，性別，年齢）

次に, 所属の会社・団体の帰宅困難を想定した計画や訓練の準備 状況と当日の指示の有無をまとめたものが図 13 である(複数回答). このとき，サンプル全体に対する回答率はそれぞれ「計画・マニュ アルなどの周知徹底をしている」が $23.0 \%$ ，「帰宅訓練をしている」 という回答が $5.4 \%$,「安否確認や緊急連絡についての訓練をしてい

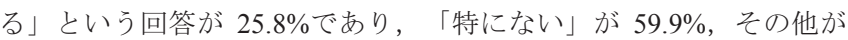
$1.4 \%$ あった．東日本大震災以降，各社で帰宅困難な状況に関する 計画や訓練が充実し始めている傾向が見て取れるものの，東京都で は2012 年 3 月 30 日に東京都帰宅困難者対策条例注6)が公布されるな ど，首都圈では積極的に帰宅困難対策が行われてきていることも考 えると, 震災後 1 年が経過した時点で約 6 割の回答者が所属する企 業で特に帰宅や安否に関する計画がなされていないという上記の点 は興味深い。さて，これらの対策状況と帰宅指示の有無の関係を見 てみたい，総じてこれらの企業で策定されている帰宅困難者対策計 画やマニュアル，安否や帰宅訓練は大震時を想定しているものと考 えられる。しかし実際に爆弾低気圧到来時に帰宅指示が出た企業ほ ど「計画・マニュアルなどの周知徹底をしている」，「帰宅訓練を している」,「安否確認や緊急連絡についての訓練をしている」と 回答した人の割合が多いことが分かった。この点は，帰宅困難者対 策の効果を示すものと言えよう. 

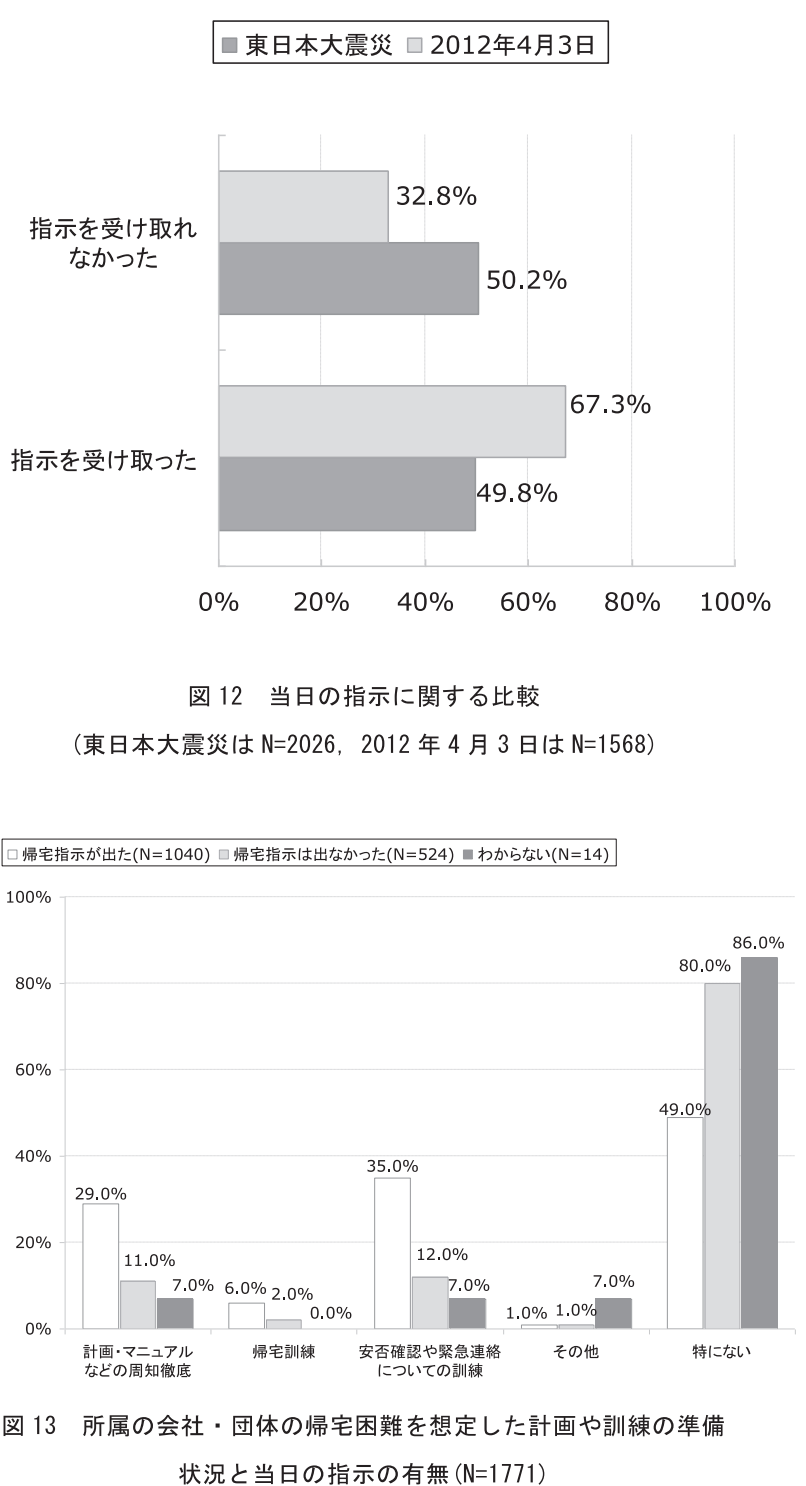

東日本大震災との比較という点で, 最後に「東日本大震災以後, どのような防災対策をとったか」についてみてみる，東日本大震災 直後に行った質問紙調查（表 2）では「今後どのような防苂対策を とろうと思うか」という設問を用意してあり，震災直後の防災対策 に関する「意向」を聞いている. 今回, 2012 年 4 月に行った質問紙 調查で「東日本大震災後にどのような防災対策をとったか」という 「実際の選択行動」を同一の選択肢のもとで尋ねており, 両者を比 較することで，それらの実施率(意向と行動の比)を探ることができ ると考えた.これは図 11 に示されるように, 同じ抽出方法を用いて 集めた同様の個人属性をもつ回答者のもとで，ほぼ同じ設問を用い て尋㸚た結果であることによる.これを図 14 に示す.はじめに安否 確認関連についてである。「家族との連絡方法を決める」について は, 2011 年 3 月末は $46.9 \%, 2012$ 年 4 月初旬は $18.2 \%$ の回答率とな つている。つまり，2011 年 3 月末に「家族との連絡方法を決める」 という対策を行おうとした人は実際に $38.8 \%$ が対策を実施している 傾向にあるという解釈ができる（これを以降では「対策の実施率」 と定義する）。また「家族が離れ離れになった時落ち合う場所を決 める」については, 2011 年 3 月末は $40.1 \%, 2012$ 年 4 月初旬は $13.2 \%$

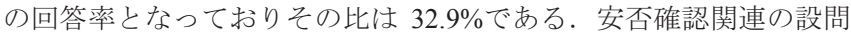
については総じて高い対策の実施率を確認することができる.

次に, 避難関連である。「突発地震の時に避難する場所を決める」 については, 2011 年 3 月末は $26.8 \%, 2012$ 年 4 月初旬は $6.5 \%$ の回 答率であり，その比は $24.2 \%$ ある。

「自宅や勤め先の安全な避難経路を確認」については，2011 年 3 月末は $18.2 \%, 2012$ 年 4 月初旬は $7.0 \%$ の回答率となっており, その 比は $38.4 \%$ ある。このことから，避難経路の確認はある程度でき ているものの, 避難場所を実際に決めた人は少ないことが分かった. また，火災対策については「消火器や水を入れたバケツを用意」 については, 2011 年 3 月末は $5.1 \%, 2012$ 年 4 月初旬は $2.3 \%$ の回答 率となっており, その比は $45.0 \%$ あ゙あ。「火器器具の周りを整理」 については，2011 年 3 月末は 7.9\%，2012 年 4 月初旬は $2.6 \%$ の回答 率となっており，その比は $32.9 \%$ であ。.それぞれ約 3 割〜 4 割の 実施率となっているものの, 東日本大震災で比較的火災の話題がク ローズアップされなかったためであろうか，対策の意向・行動とも にその絶対值は低い

次に摇れによる被害関連である。「家具が倒れないように固定」 については，2011 年 3 月末は $40.6 \% ， 2012$ 年 4 月初旬は $23.2 \%$ の回 答率となっており，その比は $57.1 \%$ あるる. 家具の固定については そもそもの意向のみならず，実施率も高い。「耐震診断」について は，2011 年 3 月末は $3.6 \%, 2012$ 年 4 月初旬は $1.1 \%$ の回答率となっ ており，その比は $30.5 \%$ である。耐震診断などはある程度実際に行 動を行うまでに時間・手間がかかるものと考えられるが，それでも 3 割の実施率が算出された。このことより, 実際大きく摇れたこと もあり, また余震を含め今後の強い摇れに関する報道などが相次い だこともあるのであろう，家具の固定をはじめとした摇れに関する 対策は首都圈である程度行われているものと解釈寸ることができる。

その他をみていく.「非常用持ち出し袋を用意する」については, 2011 年 3 月末は $54.0 \%, 2012$ 年 4 月初旬は $32.4 \%$ の回答率となって おり，その比は $60.0 \%$ で非常に高い実施率である。「地震保険」に ついては，2011 年 3 月末は $14.1 \%, 2012$ 年 4 月初旬は $5.3 \%$ の回答 率となっており，その比は $37.5 \%$ であ. 最後に「何もしない」に ついては，2011 年 3 月末は $9.1 \%, 2012$ 年 4 月初旬は $30.8 \%$ の回答 率となっている，東日本大震災直後は約 9 割の人が「何か防災対策 をしなくては」と考えていたが，その意向は各対策によって異なる ものの, 概ね 3 4 割の実施率で終わっており, 約 3 割の回答者が 1 年経過後に実際は何もしていないことがわかった，東日本大震災か ら 1 年間は, テレビ・ラジオや新聞, 雑誌など少なくともわが国で これまでにないほどの「防災教育」が社会全体で行われた時期であ り, その結果, 防災対策意向集団の中においても 3 4 割の実施率し か得られなかったという事実は, 今後の防災対策の推進方策に示唆 を与える事実と考えられる，なお，ここでは帰宅困難者対策関連の 回答として,「会社が水や食料などの備蓄品を置くようになった」 という設問があり，その回答は $8.3 \%$ とどまっている. 個人の防災 対策（非常持ち出し品など）に比べ，企業の準備はやや低い水準と 言えよう。 


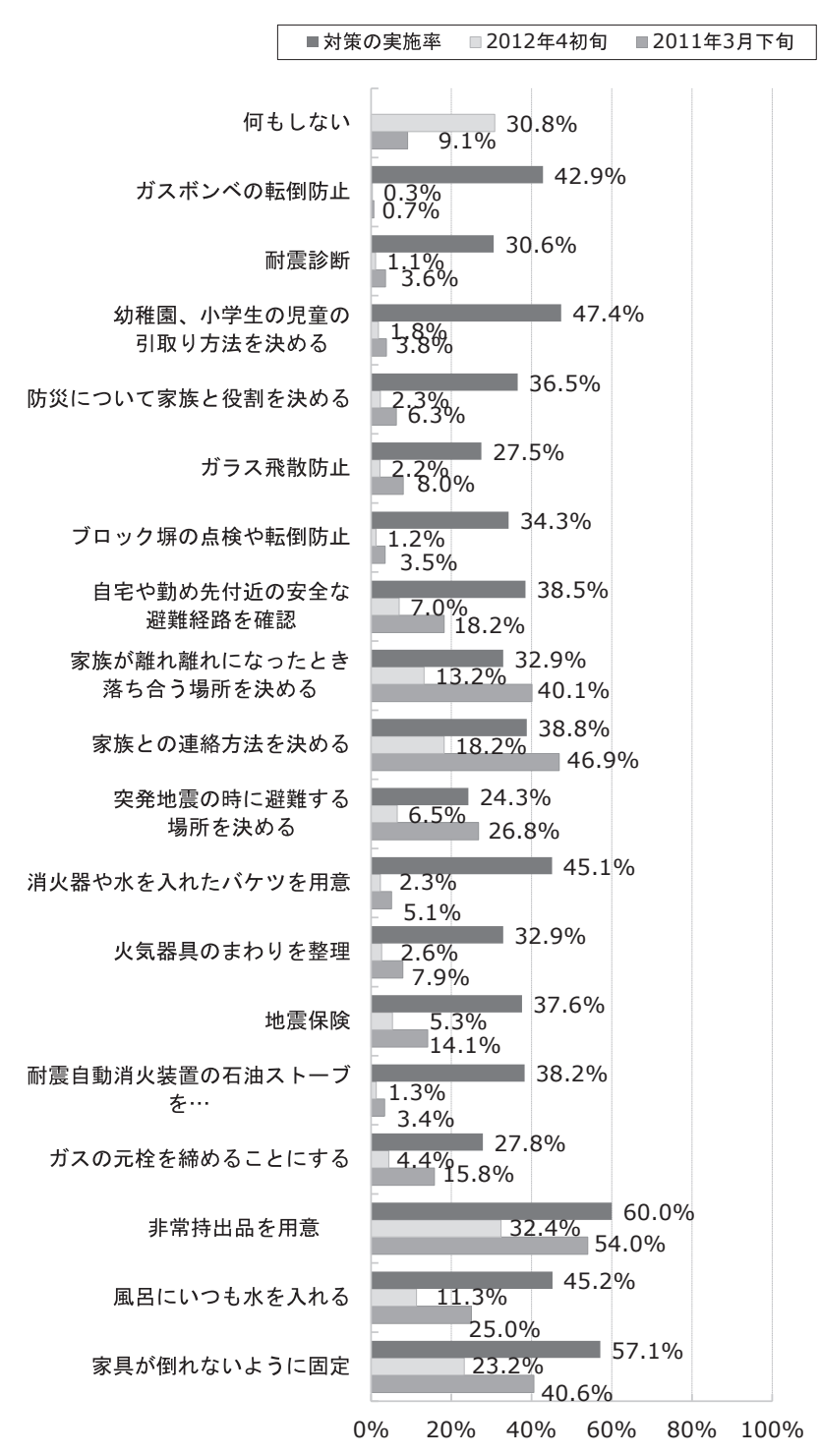

図 14 防災対策に関する意向 (2011 年 3 月下旬, $N=2026)$ と実際に 防災対策を行った割合 (2012 年 4 月初旬, $N=2158$ ), および対策の 実施率

\section{6. おわりに}

本研究は, 2012 年 4 月 3 日に我が国を襲った爆弾低気圧の認知と 対応について, 特に帰宅行動に焦点を当てて論考したものである. この結果より, 東日本大震災以降 1 年間の対策の経過を評価するこ とが可能となり，また今後の帰宅困難者対策に関する知見を企業視 点から得ることができた。本研究の成果は, 以下の 4 点に整理され る。

1. 爆弾低気圧の事前の認知は高く, 特にテレビやインターネットに よる気象情報の収集が多かった。 またその帰宅実態は, 早期帰宅を しようとした人は約 55\%であり, 帰宅を遅らせようとした人は約 7\% であり, 残りの約 $38 \%$ の人は帰宅時間を変更しようとはしていなか った.

2. 爆弾低気圧の到来に関しては, 通勤・通学者のうち約 35\%の回答 者に帰宅に関する指示が出ておらず，また指示が出た場合でもその
ほとんどが当日出勤後の指示であり, 半数が特に帰宅時間の目安を 指定しないものであった。 またその伝達方法も，口頭によるものが 約 $65 \%$ と多く，勤務中に社外にいた人は相対的に指示を受け取りに くい傾向にあることが分かった．また，指示に従わなかった人も約 $21 \%$ お, 気象災害と地震災害では八ザードの質が異なるとはいえ, 今後の帰宅困難者対策を進める上での課題と考えられる.

3. 帰宅に関する指示については東日本大震災の時よりも受け取っ た人は多かったが，他方で約 $60 \%$ の回答者は「所属の会社・団体に おいて帰宅困難を想定した計画や訓練が特にない」と回答しており， 帰宅困難者対策が進んでいない企業も多いことが明らかになった。 また「計画・マニュアルなどの周知徹底をしている」，「帰宅訓練 をしている」,「安否確認や緊急連絡についての訓練をしている」 と回答した人の企業で総じて爆弾低気圧到来時にも帰宅指示が出て おり，これらによる対策の効果も僅かながら示された.

4. 震災 1 年を経て, 震災直後に行おうと思っていた防災対策は約 3 〜4 割が実際に行われていることも判明した。特に, 家具の固定や 非常用持ち出し袋の用意は多くの回答者が実際に行っている. 他方 で, 東日本大震災直後は約 9 割の人が「何か防災対策をしなくては」 と考えたが, 結局全体の約 3 割が 1 年経過後に何もしていないこと がわかった。

以上より本研究では, 東日本大震災以降, 積極的に対策されつつ ある帰宅困難者問題について, 気象災害時の企業対応事例を通じて, 以下の示唆を得ることができた。この内容は地震時における企業の 帰宅困難者対応にも当てはまるものであり，今後の積極的な対策が 求められる.

1. 企業が鹵宅指示やその場にとどまる指示をどのように伝えるか が課題である、特に外出中の社員は指示を受け取りにくい傾向にあ り, 彼らに対して事前にマニュアルを準備しておく, 啓発を行う, 外出社員も含めた訓練を行うなどが必要と考えられる.

2. 地震災害時も爆弾低気圧襲来時と同じく, 帰宅に関する指示に従 わない社員が一定数いるものと考えられる。 どれだけこれらの指示 に実効性を持たせることができるかが課題である.

3. 東日本大震災から 1 年経過した時期においても帰宅困難者対策 が進んでいない企業がみられる。爆弾低気圧襲来時に帰宅指示が出 せた企業は「計画・マニュアルなどの周知徹底をしている」など帰 宅困難者対策を行っていた地域が多いことから，これらの対策効果 はある程度確かめることができた。

ただし爆弾低気圧襲来時の帰宅困難現象と大規模地震時の帰宅困 難現象は相違点も多いものと考えられる，そもそも，東日本大震災 時の首都圏と大規模地震時の大都市内は大きく異なる. 今後は過去 の 1,2 例のみならずより多くの知見を積み上げ，企業の帰宅困難者 対策を進める必要がある。

\section{参考文献}

1）朝日新聞デジタル：爆弾低気圧，3 人死亡 4 日も台風並み強風予測，2012 年 4 月 4 日.

2）時事通信：暴風の死者全国で 5 人に・重体の男性死亡，2012 年 4 月 5 日.

3）共同通信：東京都，企業に「一斉帰宅抑制」を要請，2012 年 4 月 3 日.

4）神奈川新聞：春の嵐・帰宅直撃，県内鉄道など大混乱，2012 年 4 月 4 日.

5）廣井悠，関谷直也，中島良太，营谷俊太郎，花原英徳：東日本大震災にお ける首都圈の帰宅困難者に関する社会調査, 地域安全学会論文集，N0.15, pp. 343-353, 2011. 
6）廣井悠，中島良太，营谷峻太郎，岩間伸之：2012 年 4 月 3 日の爆弾低気 圧到来に関する社会調査の概要, 地域安全学会梗概集, No. 30, pp73-76, 2012.

7）廣井悠，関谷直也，中島良太，葈谷峻太郎，花原英徳：東日本大震災にお ける首都圈の帰宅困難者の実態, 日本災害情報学会第 13 回研究発表会予稿 集, pp167-172, 2011.

8）気象庁：「4月の天候」，2012 年 5 月 1 日報道発表資料.

9) Frederick Sanders and John R. Gyakum : Synoptic-Dynamic Climatology of the "Bomb", Monthly Weather Review 108: pp. 1589-1606, 1980.

10）片田敏孝，本間基寛：爆弾低気圧の接近時における住民の危機意識醸成 過程に関する研究，災害情報，No. 7，pp. 84-93，2009.

11）廣井悠(編・著)，中野明保(著）：これだけはやっておきたい 帰宅困難 者対策 Q\&A，清文社，2013。

\section{注}

注 1）気象庁によるとこの結果, 観測点 889 地点のうち 76 地点で観測史上 1 位の最大風速を記録したという8)

注 2）例えば 2008 年 3 月 31 日から 4 月 1 日にかけて発生した爆弾低気圧に よって北海道東部において停電や家屋被害が記録されている。しかし，今 回の爆弾低気圧は 2 日 21 時から 3 日 21 時までに中心気圧が $42 \mathrm{hPa}$ も低下 寸る等，極めて稀な事例であった。

注 3）爆弾低気圧は 1980 年に Frederick Sanders が提唱したもので，正確に は「12 時間以上にわたり中心気圧が 1 時間あたり 1 hpa 以上低下した温帯 低気圧」と定義されることが多い9）。なお温带低気圧の場合は熱带低気圧 とは異なり，中心の風速に応じて「台風」などとの特別な呼称を用いるこ とはなく, 行政機関も特別な警戒対応を敷くことは多くない. また気象庁 は予報用語として「爆弾低気圧」の名称は用いず，「急速に発達する低気
圧」などの表現を用いている 10).

注 4）本調査においては回答者を「4月 3 日午前 10 時に首都圈に外出してい た回答者」と限定して抽出している. そのため, 前日や午前中（出勤前） に指示を受けて出勤を見合わせた回答者は十分に捉えきれておらず，出勤 前に指示があったという回答の割合は低くなってしまっている可能性もあ る. また通勤・通学者の調査対象者は 1722 人であるものの, 以降の各図に おいて関連する設問に無回答であった回答者を除いているため, それぞれ の母数が異なっている. なお, 本調査にあたっては, 居住地・性別・年齢 を均等になるようサンプリングしているため，本研究で報告する分析は 2012 年 4 月における首都圈の全体概要を示寸ものではないことに注意する 必要がある.

注 5）その他，携帯電話のメールは 3. $9 \%$, 固定電話 3. $4 \%, F A X$ が $0.7 \%$ となっ た.

注 6）東京都帰宅困難者対策条例は東日本大震災において首都圈で多くの帰 宅困難者が発生 (筆者の試算によると, 東京都全体で当日夜に帰れなかった 人は約 368 万人) したことを踏まえ， 2012 年 3 月に制定し，2013 年 4 月か ら施行したものである ${ }^{11)}$. 具体的な帰宅困難者対策に関する取り組みとし て，ここでは「一斉帰宅の抑制」，「一時滞在施設の確保」，「帰宅困難 者への情報提供」，「駅周辺における混乱防止」，「徒歩帰宅者の支援」， 「帰宅困難者の搬送」が取り上げられ，とりわけ「一斉帰宅の抑制」は個 人や企業が行うべき最重要課題とされている，本研究は，爆弾低気圧到来 時に首都圈の通勤・通学者が受け取った指示などの実例を通して, 企業を 主体とした実効性を伴う「一斉帰宅抑制」の実現について示唆を得る目的 でまとめたものである. 


\section{QUESTIONNAIRE SURVEY CONCERNING STRANDED COMMUTERS IN METROPOLITAN AREAS BY THE APPROACH OF BOMB CYCLONE ON APRIL 3, 2012}

\section{U HIROI*}

* Assoc. Prof., Disaster Mitigation Research Center, Nagoya University, Dr. Eng.

In this paper, we discuss a questionnaire survey concerning stranded commuters in the metropolitan area by approaching the bomb cyclone on April 3, 2012. Investigation areas are Tokyo, Kanagawa Prefecture, Saitama Prefecture, and Chiba Prefecture. Using Web investigation, we carried out main enumeration for 2158 commuters. We asked the situation on the day, the recognition of a weather information, its evaluation, information needs and future measures.

Based on the results of the survey, when the bomb cyclone approached, nearly 90 percent of commuters recognized arrival of the bomb cyclone beforehand. However, there were few people "tried to go home before the public transportation facility stopped" as 55.1 percent. They got information about a bomb cyclone from television (88.8 percent). Others are Internet:20.9 percent, newspaper:17.1 percent, family:10.5 percent.

Nearly 60 percent of commuters received instruction to return home at once from own company. But only 78 percent of people followed the instructions.

Many people received the directions about return home rather than the time of the Great East Japan Earthquake. And, 59.9\% of respondents answered "There are no plan and training about stranded commuters in our company." It means that there are also many companies which has no plan about stranded commuters. 